\title{
The Darkening Green
}

\section{John Gardner}

I have called and called, but no one answers. No star shows above us in the darkening sky. Wind whips the shores of the midnight lake. If they are there on the water, there is no hope for them.

But my friend's oldest boy is fifteen and knows the dangers. Surely he's put in at some cove, aware that a try at crossing back would be suicide. On the other hand-though we do not mention it to one another-it is true that he has stayed out considerably longer than he said he would, and guilt in a child (a boy fifteen is still a child) may be more powerful than reason.

I lie perfectly still, listening. My head is filled with the image-unreal as a vision-of churning waves.

My friend never shows a sign of fear. He has a theory, which he tells me from time to time, forgetting he's told me the theory before, about "necessary risk." No creature grows strong, he always tells me, without testing itself. I agree, of course. He tells me also, with childlike openness, of reincarnation. On that I make no comment. He came into the room in his swimming suit. The three of us sat-my wife and I and my friend's wife-talking and drinking in the yellowred glow of the fireplace, warm with friendship that hovered between philosophical and sensual, unaware that the children were still on the lake. $\mathrm{He}$ listened, smiling, half lost in a dream, to our slightly drunken talk. He himself never drinks. When his sloe-eyed wife looked up at him, he asked casually, "Is Ronnie back?"

"Hours ago," his wife answered, with the curious irony I have never understood, common as it is among attractive women. All she says, it seems to me, is sexually suggestive, and though my wife is beautiful, her red hair glowing like newly cut copper in the firelight, I am by no means left untempted. My friend's wife has slanting eyes, an oval face, perfectly fashioned dove-soft breasts magnificently lined in her snow-white swimsuit. What makes her mysterious-I know, at least intellectually-is that her dark hair is dyed bright yellow, which ought to be disgusting but comes off, because she is full of strange fancies, as wicked, seductive, self-consciously meretricious.

"The boat's not back," my friend said. "Or did they put it away?" He stood smiling blandly, rubbing his hands, his body totally divorced from his mind.

My wife sat up with a jerk and glanced out the cabin window. The sky had an eerie purple cast, a look one knows only too well if one has lived very 
long in Southern Illinois. Tornado weather. My friend stood watching her, smiling for help, his great tanned shoulders rippling with the agitated rubbing of his short, strong hands. "We'd better look," my wife said, collecting her balance and rising, with the help of one arm, to her feet. She went past him, excessively graceful-just slightly overcompensating for the vodka buzz-and went out onto the porch, into the wind, her glass between her fingertips. She called out shrilly, like an older sister. There was no possibility of their hearing her. We followed and tried to help her, leaning on the railing, shouting. The roar of the wind in the oaks all around was like the rumble of a train. In the break between trees, a hundred yards below, we could see the whitecapped waves.

Quickly, silently, my friend went down the wooden steps and on down the slick clay path toward the motorboat. As soon as we understood, we followed. $\mathrm{He}$ had the motor running as I jumped aboard. He called to the women to stay, but they ignored him. They leaped to the slippery foredeck, holding hands like children. I caught their two free hands and helped them back past the windshield to the wave-soaked seats. The boat veered out toward the center of the lake, tilted like a shark, malevolent.

I have an image of him, standing at the wheel, absurdly smiling though he had, heaven knows, no wish, no reason-except for his theory of risk-to smile. There was a whistle above us, unearthly wind, and the cry of the motor was human, despairing, totally, terribly isolated in the stern and turbulent night. The boat moved forward by grotesque leaps. At the center of the lake, the waves were six feet high. There was no thought of turning or taking that terrible force aslant. We clung to each other, the two women and I. My friend stood smiling grotesquely at the wheel. As the boat bounced near the further shore he slowed the motor-the waves were now lower-and stood peering, smiling, from side to side, the muscles of his back and arms bulging, the steering wheel still as a rock in his powerful hands. Then, abruptly, he shut off the motor. The boat leaped, released to the anger of the lake. He stood like a mast, still hunting, smiling like a madman. On the shore, among the pitchdark trees, there was no sign of life, no trace of their canoe. We shouted, all four of us. The wind tore away our cries like sparks. We were drenched, our hair streaming into our eyes.

"They'd make a fire," he said. Strangely, despite the shriek of wind, his words came through undistorted.

There was, of course, no sign of fire, much less any answer to our frantic shouts. Abruptly, the trees on the shore went still; the shriek of the wind fell silent, as if swallowed back. As if hardly aware that he was doing it, he started the motor, flipped the boat around, and shot straight back in the direction from which we'd come. There was now no motion whatever above us. The lake rocked, sickening, but not from wind. The motor screamed-on, off, like a heart. He stood stiffly at the wheel. The lightning flickered steadily. The twister came stern and serene from the south. I watched it, calm as a creature arrested by the paws of a lion-if reports are true, if the instant of death is an instant of supreme tranquility. And so, in a kind of dream, I floated through the moment of the crash. He struck full-ahead, and the boat plowed thirty feet ashore before it toppled, throwing us, screaming mechanically to itself. My wife 
lay unconscious, strangely beautiful in the purple light. I heard him screaming, but I could not locate the source of the scream. "Surely the boy has put in at some cove," I thought. Numb. My white-headed children are seven and five, the boy philosophical and gentle as a deer, his sister cunning, mysterious.

I found his wife clinging to the bole of an oak, unharmed except for a badly scratched face. Her terror amused me-she who was always so fond of the ironic, she who played goddess in a world of helpless children. I crawled back to my own wife. She was still out cold, but she'd suffered no harm. Gently, I carried her to the shelter of trees. He was still screaming, but now it came to me that it was not from pain. He was calling to the children, as before. I too called to them, again and again. It was absurd, of course. I did it from guilt, to prove myself no less concerned than my friend. I came to my senses at last and gave up. I crawled back to where his wife lay crying. Her swimsuit was torn, so that her left breast lay fully exposed. Slowly, shyly, as if I were a child of fourteen again, I moved my hand from her throat to her nipple. When I looked at her face, I saw that her slanted eyes were watching me, excited. My own wife, ten feet away, lay faintly glowing. I could hear the husband, calling even now for the children-his own, tall and lithe as an Indian, and mine, white-headed, insubstantial as saints ....

"Mmm," she said and rolled her face away.

The trees groan and shudder as the outer wheel of the whirlwind strikes. The motorboat flops, as if by volition, and flies to the darkness of trees. I cling to her, crushing my lips to hers and tearing at the swimsuit. Rain smashes in. The sky is bright green.

Surely a boy-a young man-of fifteen . . .

Surely my children, insubstantial as saints . . .

I hear them screaming, more near than my skin. We jerk up, violently shaking, and scream their names. 